THE FOREST DEPARTMENT OF INDIA.

THE Government of India has issued a pamphlet of sixty-five pages, entitled "The Work of the Forest Department of India," by Mr. R. S. Troup. This gives in popular form, and at the low price of $5 d$., an account of the forests of India, and of the methods by which they are protected and managed. The Forest Department controls one-fifth of the total area of India, viz. 249,867 square miles; but no fewer than I4I,882 square miles of this are so-called "unclassed" forests, where control is nominal, being restricted to the collection of revenue. Of the "reserved" and "protected" forests, ro 7,985 square miles in area, about one-half, 55,629 square miles, are scientifically managed and subject to sanctioned working plans. The most important commercial forests are the teak forests of Burma, the sal forests of Northern, Central, and North-Eastern India, and the deodar and pine forests of the North-Western Himalaya. Forests yielding inferior kinds of timber are scarcely less important, as they provide wood, fuel, fodder, and other produce for the surrounding agricultural population. The personnel of the Forest Department includes 237 officers trained in England, $23 x$ officers recruited in India and trained at Dehra Dun, and a subordinate service of I6 10 rangers, 2000 foresters, and Io,500 forest guards. The Forest Research Institute of Dehra Dun, which was founded in 1906 , prosecutes investigations in sylviculture, forest botany, economic products, zoology, and chemistry, and has already issued a considerable output of scientificliterature. The pamphlet contains a valuable list, with short descriptions of the forty-four most important forest trees, and an excellent chapter on minor produce, which includes bamboos, grasses, fibres, oil seeds, tanning materials, essential oils, oleo-resins, gums, india-rubber, drugs and spices, and animal products like lac, silk, horns, hides, and ivory. An interesting account is also given of various forest industries which have been established by the Forest Department, such as the tapping of Pinus longifolia for resin and turpentine, which has now passed out of the experimental stage, the annual collection amounting to 2592 tons. The paper-pulp industry, the manufacture of matches, the antiseptic treatment of timber, and the dry distillation of wood are industries which appear to be capable of considerable development in India.

THE GREAT ERUPTION OF SAKURA-JIMA.

PROF. F. OMORI, the well-known director of the

Seismological Institute of Tokyo, has recently issued a third valuable memoir on the great eruption of the Sakura-jima on January 12, 1914 (Bull. Imp. Earthq. Inv. Com., vol. viii., December, Ig16, pp. 181-321). The first two memoirs have already been noticed in Nature (vol. xciv., p. 289, 1914, and vol. xcviii., p. 57 , I916). The third memoir is principallv concerned with details which, though of great value, are unsuitable for reproduction in a note. "Two or three points, however, are of general interest. On and around the plateau of Hakamagoshi, which projects from the west side of the island, there are unmistakable signs of the generation of volcanic blasts. The school-house was entirely destroyed and carried away. On a farm near the top of the plateau a great number of large mandarin-orange trees were uprooted and carried some distance up a slope. The blasts were directed principally against the north-east corner of Hakamagoshi and the neighbouring village of Koike. The destruction here was general, and the tree-trunks were mostly overthrown or broken between two directions which, when produced backwards, passed through the highest and NO. 2498 , VOL. IOO] lowest of the western series of craterlets. On the east side of the island no distinct trace of the blast could be detected. Before the eruption the island was separated from the mainland on the east side by the Seto Strait, which, in its narrowest portion (400 metres in width), varied in depth from 29 to 40 fathoms. The lava entered the strait on the morning of January 13 , blocked it up after sixteen days, and finally rose in height to about 54 metres above the sea. The movement of the lava stream on this side ceased with the close of 1914. About three months later there took place a second outflow of lava, not directly from the craterlets, but from the southern face of the southeastern lava-field. The new outflows expanded into a form like that of a chrysanthemum leaf, the greatest elongation amounting to nearly 900 metres.

Prof. Bundjiro Kotō has published (Journal of the College of Science, Tokyo, vol. xxxviii., art. 3, December 25 , I9I6) a comprehensive and handsomely illus trated account of the same eruption. The author reached the city of Kagoshima on January I5, I9I4, and saw the great lava-sheets flowing from the volcanic island, a most unusual spectacle among the explosive volcanoes of Japan. The tremendous "Strom bolian" outburst of January 12, when the fragmental matter rose as a great cloud-pillar to a height of more than 18,000 metres, is shown in the photographic frontispiece, which forms a most memorable addition to our historic pictures of volcanoes. The inhabitants of the island were rescued in boats by volunteers from the shore of Kyûshû, and traversed a pumice-laden sea. The ejected materials, which are described in petrographic detail, consist of femic augite-andesite. There is evidence in the scorched trees of a nuée ardente, like those of Martinique, which spread down the western slope on the early morning of January I3. Among the ejecta are many resembling porcelain, and composed of cordierite, plagioclase, and glass. This type has been described from Asama-yama, and Prof. Kotō now styles it ceramicite.

\section{THE DISSEMINATION OF FUNGUS DISEASES.}

VERY little has been heard of the International Phytopathological Convention of Rome since the outbreak of hostilities, but there is little doubt that the subject will be revived when terms of peace are settled or shortly afterwards. A careful consideration of its proposals is, therefore, all the more necessary at the present time, and the reasoned criticism published by Dr. E. T. Butler, the Imperial Mycologist, in vol. ix., No. 1 , of the Memoirs of the Department of Agriculture in India, on the dissemination of parasitic fungi and international legislation is doubly welcome from both the scientific and the administrative points of view.

Dr. Butler discusses, in the first place, the various methods by which sucl; fungi may be conveyed over great distances, and decides that little is to be feared from natural means, the chief agent being civilised man engaged in commerce. He then recounts some of the attempts that have been made to control the spread of plant diseases by legislation, and criticises the procedure proposed by the Rome Convention, chiefly, of course, with reference to the conditions under which India is situated.

The weak points in the Convention, especially those caused by the loose phraseology of the much-debated Article 5, are duly pointed out, but Dr. Butler concludes with the opinion that, subject to certain necessary amendments, and if certain clauses are broadly interpreted, there are obvious advantages in adhering to it, and that "after a few years' experience, and as soon 